Stanisław Witkowski MS

\title{
Współukrzyżowani z Chrystusem i wolni od mocy grzechu (Rz 6, 1-14)
}

Fragment Rz 6, 1-14 podejmuje temat relacji między grzechem a łaską. Jest on tak istotny, iż wersety 1-11 należą w piśmiennictwie Pawłowym do najbardziej znaczących tekstów. Stanowią one dla wierzącego fundament o charakterze mistycznym ${ }^{1}$. W centrum perykopy znajduje się nie ryt chrztu, lecz udział wierzącego w śmierci i zmartwychwstaniu Chrystusa ${ }^{2}$. Odwołanie się do chrztu ma na celu podkreślenie nowości ontologicznej człowieka, wynikającej z jego uczestnictwa w zbawczym wydarzeniu Chrystusa.

Rz 6, 1-14 stanowi pierwszą dyskusję diatrybiczną w bloku Rz 5, 1-8, 39. Wcześniej styl diatryby pojawił się w Rz 2, 1-3, 20. 27-31. Wyróżnia go stawianie pytań, natychmiastowe odpowiedzi, a także personifikacja grzechu $^{3}$ - jest on widziany jako osoba, zniewalająca moc, która panuje nad życiem wierzącego.

W Rz 6, 1-14 można wyróżnić trzy zasadnicze części: tezę wprowadzającą w formie pytania dotyczącego relacji między grzechem a łaską (w. 1); natychmiastową odpowiedź stwierdzającą brak jakichkolwiek relacji między grzechem a łaską (ww. 2-11); końcową zachętę, by nie dać się ponownie zwyciężyć przez grzech, lecz pozostawać pod wpływem łaski (ww. 12-14)4.

Obecność imperatywów w konkluzji w wersetach 12-14 ukazuje, że dialog z fikcyjnym rozmówcą w ww. 1-2 nie jest celem samym w sobie,

${ }^{1}$ Por. R. Penna, Lettera ai Romani, t. 2: Rm 6-11, Bologna 2006, s. 15 (Scritti delle origini cristiane, 6). Wersety zaś 12-14 stanowią logiczną kontynuację ww. 1-11 mającą wydźwięk moralny.

${ }^{2}$ Por. J. E. Toews, Romans, Scottdale, Pensylvania-Waterloo, Ontario 2004, s. 305 (Believers church Bible commentary).

${ }^{3}$ Por. A. Pitta, Lettera ai Romani, Milano 2001², s. 243 (I Libri Biblici. Nuovo Testamento, 6).

${ }^{4}$ Por. tamże, s. 243. Nieco inną strukturę proponuje S. Légasse. Również wyodrębnia w 6,1-14 trzy części, jednak inaczej dzieli wersety, a główną tezę dostrzega w wersecie 2. Jego zdaniem omawiany fragment należałoby podzielić następująco: ww. 1-2 wyrażają kwestię i odpowiedź, która stanowi tezę; ww. 3-10 stanowią obronę tezy za pomocą argumentacji; ww. 11-14 są aplikacją tezy w życiu chrześcijan - por. S. Légasse, Etre baptisé dans la mort du Christ. Étude de Romains 6, 1-14, „Revue Biblique” 98 (1991) nr 4, s. 546. 
lecz występuje w funkcji zachęty moralnej skierowanej do adresatów listu ${ }^{5}$. Perykopa tworzy zwartą jedność literacką. Początkowe „Cóż więc” (Tí oưv) zostaje podjęte w wersecie 15, który wprowadza inną sekcję. Poza tym dostrzegamy inkluzję pomiędzy wersetem pierwszym a czternastym. W obydwu bowiem pojawiają się te same terminy: „grzech” $-\dot{\alpha} \mu \alpha \rho \tau i \alpha$ oraz

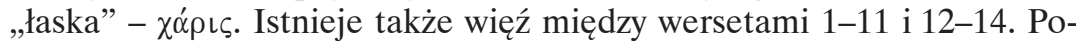

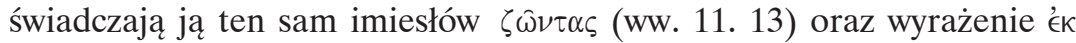
$\nu \in \kappa \rho \omega ิ \nu$ (ww. 4. 9. 11. 13).

\section{Główna teza: grzech a łaska (w. 1)}

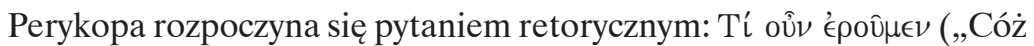
więc powiemy"). W myśli Pawłowej zawsze oznacza ono zwrot, stanowi element strukturalny, typowy w rozwoju argumentacji w Liście do Rzymian ${ }^{6}$ (por. 3, 1. 5. 9; 4, 1; 6, 1. 15; 7, 7; 8, 31). Nie występuje w innych listach Pawłowych oprócz Ga 3, 19.

Wprowadzającemu pytaniu towarzyszy kolejne, które zawiera tezę perykopy: czy trwanie w grzechu gwarantuje obfitość łaski? Paweł czuł się zobowiązany podjąć tę kwestię przede wszystkim ze względu na stwierdzenie: „Gdzie jednak wzmógł się grzech, tam jeszcze obficiej rozlała się łaska” $(5,20)$. Nadto w 3,8 czytamy, że oskarżono go, iż głosi antymoralność, by mogła objawić się pobłażliwość Boża ${ }^{7}$. Zarzut zawarty w 6,1 nie był więc teoretyczną hipotezą, miał swe źródło w błędnym rozumieniu doktryny Pawłowej. Fałsz wyrażał się w przekonaniu, że grzech wydaje się konieczny, by mogła okazać się łaska.

"Grzech" ( $\dot{\alpha} \mu \alpha \rho \tau i ́ \alpha)$ pojawia się w Rz 6 aż 16 razy, zawsze występuje w liczbie pojedynczej i wyraża moc wcześniejszą niż pojedyncze akty grze$\mathrm{chu}^{8}$. Panuje ona nad wszystkimi i czyni ich niewolnikami ${ }^{9}$.

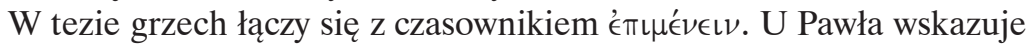
on zawsze na stabilne trwanie (por. Rz 11, 22. 23; 1 Kor 16, 7-8; Ga 1, 18; Flp 1, 24; Kol 1, 23; $1 \mathrm{Tm} 4,16)$. Konstrukcja z celownikiem bez przyimka

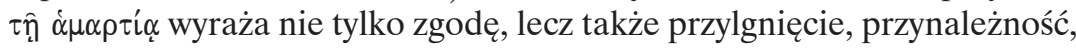
niemalże uczestnictwo ${ }^{10}$.

${ }^{5}$ Por. A. Pitta, Lettera ai Romani, dz. cyt., s. 243.

${ }^{6}$ Por. R. Penna, Battesimo e partecipazione alla morte di Christo in Rom 6, 1-11, [w:] L ‘apostolo Paolo. Studi di esegesi e teologia, Torino 1991, s. 150.

${ }^{7}$ Por. S. Légasse, Etre baptisé dans la mort du Christ..., art. cyt., s. 541.

${ }^{8}$ Por. R. Penna, Battesimo..., dz. cyt., s. 154.

${ }^{9}$ Por. A. Pitta, Lettera ai Romani, dz. cyt., s. 244.

${ }^{10}$ Por. R. Penna, Lettera ai Romani, dz. cyt., t. 2, s. 20. 
Paweł pyta więc, czy mamy zgodzić się na grzech, przylgnąć do niego? Nie ma on przecież żadnej mocy twórczej, lecz tylko i wyłącznie niszczycielską. To nie on rodzi łaskę, lecz tajemnica paschalna ${ }^{11}$.

\section{Śmierć dla grzechu i misterium chrztu (ww. 2-4)}

Paweł jednoznacznie stwierdza, że nie ma współistnienia między grze-

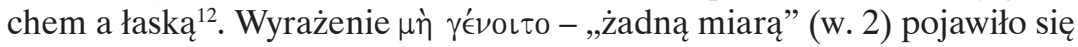
już w Rz 3, 6.31. Należy ono do stylu diatryby i zawiera w sobie pragnienie, by dana rzecz się nie spełniła ${ }^{13}$.

W ten sposób Paweł chce wyraźnie odłączyć się od tych, którzy zgadzają się z tezą wyrażoną w wersecie 1 . Jednocześnie przypomina, że „umarliśmy

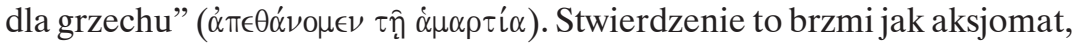
ma charakter rozstrzygający, radykalny ${ }^{14}$. Łączy nadawcę i adresatów listu. Obejmuje także każdego chrześcijanina ${ }^{15}$.

Paweł przywołuje wydarzenie śmierci, która już miała miejsce i naznaczyła wierzących w głębiach ich jestestwa. W kolejnych wersetach wyjaśni, co to znaczy umrzeć dla grzechu. Teraz zaś wykazuje jedynie istniejącą sprzeczność: jak można żyć pod władzą grzechu, skoro się dla niego umarło ${ }^{16}$.

Kolejne pytanie retoryczne rozpoczyna egzegezę śmierci dla grzechu na tle tajemnicy chrztu. Wyrażenie „czy nie wiecie, że” nawiązuje do poprzedniej myśli ${ }^{17}$ i ma na celu zwrócenie uwagi na to, co zostanie prze-

\footnotetext{
${ }^{11}$ Por. List do Rzymian, tł., wstęp i koment. H. Langkammer, Lublin 1999, s. 80 (Biblia Lubelska).

${ }^{12}$ Łaska oznacza nowy porządek istnienia, nową kondycję człowieka na mocy usprawiedliwiającego czynu Boga - por. Rz 5, 2.

${ }^{13}$ Forma $\gamma^{\prime} \in \operatorname{vo\iota } \tau$ stanowi optativus cupitivus, wyraża życzenie możliwe do spełnienia - por. F. Blass, A. Debrunner, F. Rehkopf, Grammatik des neutestamentlichen Griechisch, Göttingen $1984^{16}$, par. 384 .
}

${ }^{14}$ Por. R. Penna, Lettera ai Romani, dz. cyt., t. 2, s. 20.

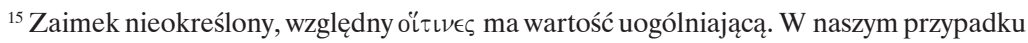
zastępuje $\dot{\eta} \mu \epsilon \hat{\imath} \varsigma$ („my”) - por. R. Penna, Lettera ai Romani, dz. cyt., t. 2, przypis 25 na s. 20.

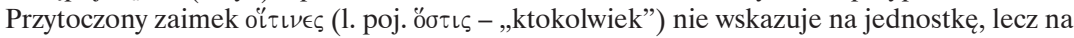
gatunek - por. M. Golias, Wstępna nauka języka greckiego, Warszawa 1981, uw. 166, s. 51.

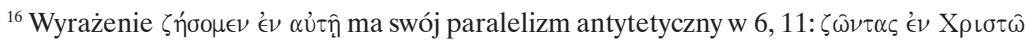
'I $\rceil$ бov̂; wskazuje on przejście spod panowania grzechu pod panowanie Chrystusa - por. R. Penna, Battesimo..., dz. cyt., 154.

${ }^{17}$ Spójnik $\eta$ występuje na początku zdań pytających i interpretujących myśl wcześniejszą - por. R. Popowski, ク̆, Wielki słownik grecko-polski, Warszawa 1995, s. 259, 2. 
kazane (por. Rz 1, 13; 11, 25). Wypowiedź Pawła w wersecie 3 jest ujęta $\mathrm{w}$ formie chiazmu ${ }^{18}$.

A $€ ß \alpha \pi \tau i ́ \sigma \theta \eta \mu \epsilon \nu-$, zostaliśmy ochrzczeni”

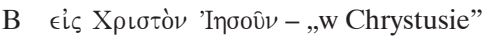

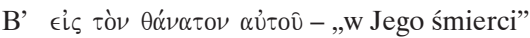

A' $€ ß \alpha \pi \tau i \sigma \theta \eta \mu \eta \nu-, z o s t a l i s ́ m y ~ o c h r z c z e n i ”$

Centrum chiazmu tworzy B-B'. Z tekstu wprost wynika, że chrzest łączy nas z Chrystusem, z Jego śmiercią. Śmierć Jezusa jest wydarzeniem, które poprzedza chrzest, tworzy jego fundament i nadaje mu sens ${ }^{19}$. Dlatego też chrzest chrześcijański nie stanowi - jak zauważyliśmy we wstępie - tematycznego centrum Rz 6, 1-14. Reprezentuje aspekt drugorzędny, funkcyjny.

„Być ochrzczonym [zanurzonym] w Chrystusie Jezusie” ma swój synonim

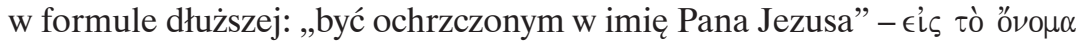

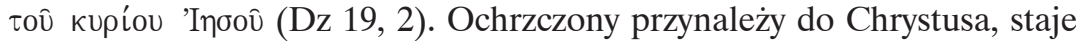
się Jego własnością, jest z Nim zjednoczony ${ }^{20}$. Zjednoczenie z Chrystusem stanowi więc w Rz 6, 1-14 centrum myśli Pawłowej ${ }^{21}$. Potwierdza to także przyimek $\epsilon$ ic. W naszym kontekście zachowuje on pierwotne znaczenie ruchu w odróżnieniu od ' $\epsilon$, które wskazuje na stanie w miejscu. Eıৎ opisuje nie tylko przeniesienie, lecz także przylgnięcie intymne, osobowe, współudział² ${ }^{22}$

W kontekście chrztu Jezusa w Mk 1, 9 w wersji oryginalnej czytamy:

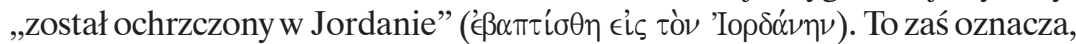
że był zanurzony ( $\beta \alpha \pi \tau i \zeta \in \iota \nu$ - „Zanurzać, udzielać chrztu”) w Jordanie, ogarnięty jego falami. Analogicznie chrześcijanin przez chrzest jest ogarnięty, objęty przez Chrystusa ${ }^{23}$. Żyje z Nim w realnej, a nie symbolicznej jedności ${ }^{24}$.

Wspomniany chiazm kładzie również nacisk na udział ochrzczonego w śmierci Chrystusa ${ }^{25}$. Po stwierdzeniu, że umarł On dla nas (por. Rz 5, 6. 8 - w wersetach tych występuje przyimek úmé $\rho$ opisujący korzyść), teraz Paweł pragnie podkreślić nasze współuczestnictwo w Jego śmierci (akcentuje je

${ }^{18}$ Por. S. Légasse, L'épître de Paul aux Romains, Paris 2002, s. 393 (Lectio divina, 10).

${ }^{19}$ Por. R. Penna, Battesimo..., dz. cyt., s. 159.

${ }^{20}$ Jedność ochrzczonych z Chrystusem jest szczególnie zaakcentowana w naszej pery-

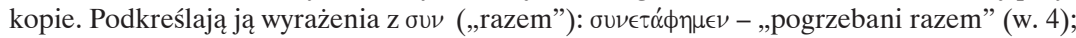

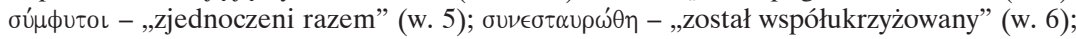

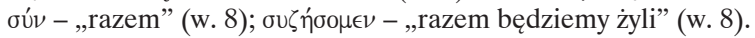

${ }^{21}$ Por. J. E. Toews, Romans, dz. cyt., s. 307.

${ }^{22}$ Por. R. Penna, Lettera ai Romani, dz. cyt., t. 2, s. 22.

${ }^{23}$ Por. tamże, s. 23.

${ }^{24}$ Por. J. A. Fitzmyer, Lettera ai Romani, trad. di E. Gatti, ed. italiana a cura di A. Pitta, Casale Monferrato 1999, s. 517.

${ }^{25}$ Paweł nie jest pierwszym, który ustanawia relację między chrztem a śmiercią. Sam Jezus określał własną śmierć jako chrzest - por. Mk 10, 38-39; Łk 12, 50. 


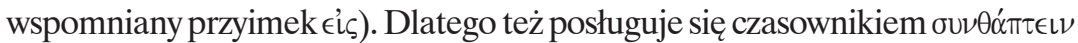
(w. 4) w aoryście, który uwypukla nasze współpogrzebanie z Chrystusem jako już zaistniały fakt. Paweł obwieszcza więc w sposób definitywny prawdę o naszej śmierci z Chrystusem. Złożenie do grobu jest bowiem pieczęcią, ostatecznym potwierdzeniem rzeczywistości śmierci ${ }^{26}$. Ochrzczony uczestniczy, „ma udział” w śmierci i pogrzebaniu Chrystusa, ale nie dzieli z Nim jeszcze Jego zmartwychwstania. Paweł uznaje je bowiem jako wydarzenie ściśle eschatologiczne, a nie jako naturalną konsekwencję współudziału w śmierci Chrystusa. Zmartwychwstanie będzie darem Bożym dla tych, którzy wytrwają

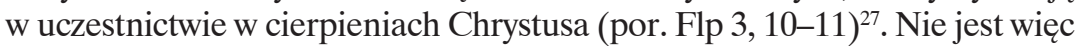
ono faktem aktualnym, ale - jak zaznaczyliśmy - eschatologicznym.

Dostrzegamy w tym punkcie zasadniczą różnicę między Listem do Rzymian a Listami do Kolosan i Efezjan. W pierwotnej myśli Pawłowej chrzest występuje w bezpośredniej relacji do śmierci Chrystusa. Natomiast w listach deuteropawłowych łączy on chrześcijanina także z Jego zmartwychwstaniem. Nie tylko zostaliśmy z Nim współpogrzebani, ale także jesteśmy z Nim współzmartwychwstali.

Tymczasem Rz 6, 4 podkreśla, że obecnie odpowiednikiem zmar-

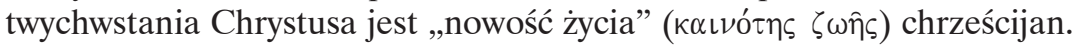
Znajduje ona swój fundament w Jego powstaniu z martwych ${ }^{28}$. Nie można jej wypracować własnym jedynie wysiłkiem. Jest bowiem jakością eschatologiczną ${ }^{29}$ (por. Rz 7, 6; 12, 2; 2 Kor 5, 17; Ga 6, 15), oznacza pełnię wartości podarowaną chrześcijanom dzięki zbawieniu dokonanemu przez Chrystusa $^{30}$. Stanowi także potwierdzenie, iż moc eschatonu wkroczyła

${ }^{26}$ Por. S. Agersnap, Baptism and the New Life. A Study of Romans 6, 1-14, Aarhus 1999, s. 269. Légasse dostrzega w uwadze dotyczącej współpogrzebania przygotowanie do wydobycia jeszcze większego kontrastu między śmiercią a zmartwychwstaniem. Zmarły zostanie bowiem podniesiony z pozycji, którą zajmował w grobie - por. S. Légasse, L'épître..., dz. cyt., s. 394. Odniesienie do pogrzebania mogłoby także kojarzyć się z liturgicznym gestem chrzcielnym zanurzenia w wodzie. Jednak w tekście nie mamy odpowiednika współpowstania z martwych, czyli do wynurzenia. Nadto z czasów Nowego Testamentu nie posiadamy również potwierdzeń dotyczących takiego właśnie sposobu praktykowania chrztu - por. A. Pitta, Lettera ai Romani, dz. cyt., s. 247-248. Jedynie począwszy od Constitutiones Apostolorum 3, 17, 3 ryt chrztu jest interpretowany w świetle Rz 6. Czynność zanurzania oznacza symbolicznie umie-

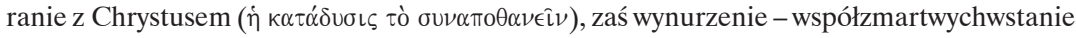
z Nim - por. R. Penna, Battesimo..., dz. cyt., s. 161.

${ }^{27}$ Por. A. Pitta, Lettera ai Romani, dz. cyt., s. 248.

${ }^{28}$ Por. List do Rzymian, dz. cyt., s. 80.

${ }^{29}$ Por. D. Zeller, Der Brief an die Römer, Regensburg 1984³, s. 124 (Regensburger Neues Testament).

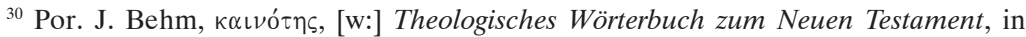
Verbindung mit O. Bauernfeind... [et al.] hrsg. von G. Kittel, t. 3, Stuttgart 1935, s. 453. 
w obecny wiek ${ }^{31}$. Nowość życia (por. 7, 6) czyni aluzję do nieznanego do tej pory typu egzystencji, nawiązuje do postawy człowieka, która wymyka się schematom tego świata (por. Rz 12, 2) ${ }^{32}$. Ideę nowości życia wzmacnia także czasownik $\pi \epsilon \rho \iota \pi \alpha \tau \epsilon i ̂ \nu$. Dosłownie oznacza „chodzić wokół”, metaforycznie zaś opisuje u Pawła przede wszystkim prawe, etyczne życie

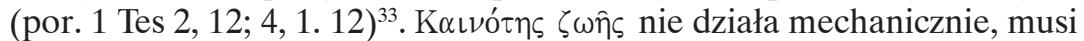
być weryfikowana ${ }^{34}$. Jej wartość jest niepodważalna. Chociaż bowiem nie oznacza jeszcze współudziału ochrzczonego w chwalebnym zwycięstwie Chrystusa, to jednak jest dowodem, że Chrystus został wskrzeszony przez chwałę, czyli przez moc (por. 2 Kor 13, 4) Ojca ${ }^{35}$. Potwierdza, iż stała się ona dostępna dla chrześcijanina dzięki zmartwychwstaniu Chrystusa.

\section{Zjednoczenie z Chrystusem i śmierć starego człowieka (ww. 5-7)}

Werset 5 ponownie podkreśla uczestnictwo wierzących w śmierci Jezusa i szczególnie akcentuje nasz przyszły udział w Jego zmartwychwstaniu.

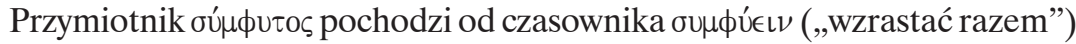
i oznacza „zjednoczony, zrośnięty, tego samego rodzaju, tej samej natury”. Termin ten występuje w Nowym Testamencie jedynie w Rz 6, 5 i łączy się

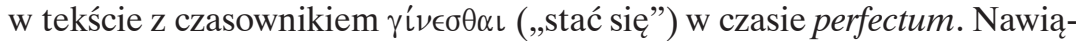
zuje zatem do faktu, który zaistniał w przeszłości, a jego skutki są wciąż

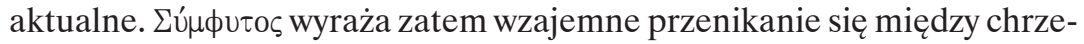
ścijanami a Chrystusem ${ }^{36}$. Spójność ta dokonała się na krzyżu i nadal trwa.

Dyskusję wzbudza rzeczownik ó $\mu$ ó $\omega \mu \alpha$. Jego znaczenie jest trudne do uchwycenia, ponieważ rzadko występuje w tekstach klasycznych. Wskazuje w nich na identyczny obraz, wizerunek, także podobieństwo, zgodnośćc ${ }^{37}$. W LXX termin ten występuje czterdzieści razy i może oznaczać w sensie konkretnym „obraz” (por. Wj 20,4) oraz bardziej ogólnie - „porównanie” (por. Iz 40, 18) lub „postać, dostrzegalną formę” (por. Ez 1, 26).

${ }^{31}$ Por. J. E. Toews, Romans, dz. cyt., s. 310.

${ }^{32}$ Por. R. Penna, Lettera ai Romani, dz. cyt., t. 2, s. 28.

${ }^{33}$ Por. S. Agersnap, Baptism and the New Life..., dz. cyt., s. 269, oraz H. Seesemann, $\pi \epsilon \rho\left\llcorner\pi \alpha \tau^{\prime} \omega\right.$, [w:] Theologisches Wörterbuch zum Neuen Testament, begründet von G. Kittel; in Verbingung mit zahlreichen Fachgenossen hrsg. von G. Friedrich, t. 5, Stuttgart 1954, s. 944.

${ }^{34}$ Por. H. Schlier, Der Römerbrief, Freiburg-Basel-Wien 20024, s. 194 (Herders Theologischer Kommentar zum Neuen Testament, 6).

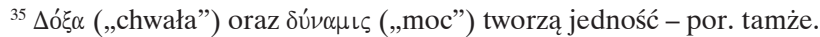

${ }^{36}$ Por. R. Penna, Lettera ai Romani, dz. cyt., t. 2, s. 30.

${ }^{37}$ Por. J. Schneider, ó $\mu$ oío $\mu \alpha$, [w:] Theologisches Wörterbuch zum Neuen Testament, dz. cyt., t. 5, s. 191. 
W Nowym Testamencie słowo to pojawia się sześć razy (pięciokrotnie u Pawła). W Rz 1, 23; 5, 14 oraz w Ap 9, 7 ma ono znaczenie podobieństwa $^{38}$, zaś w Rz 8, 3 i Flp 2, 7 oznacza „postać, figurę, kształt” i opisuje ludzką naturę Jezusa ${ }^{39}$.

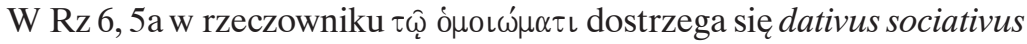
i znaczenie podobieństwa lub dativus instrumenti i znaczenie zgodności w sensie współudziału. W pierwszym przypadku zdanie brzmiałoby: „Jeśli bowiem zostaliśmy zjednoczeni w podobieństwie do Jego śmierci...."40. Rzeczownik $\tau \hat{\omega}$ ó $\mu \circ \iota^{\prime} \mu \alpha \tau \iota$ łączy się wtedy bezpośrednio z przymiotnikiem

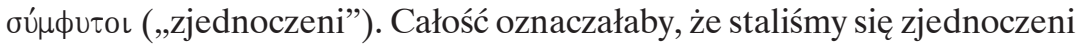
ze śmiercią Jezusa. Jednak nasza śmierć nie jest identyczna z Jego śmiercią, nie oznacza tego samego losu ${ }^{41}$.

W drugim przypadku przekład brzmiałby: „Jeśli bowiem zostaliśmy zjednoczeni z Nim przez współudział w Jego śmierci..." ${ }^{42}$. Dostrzegamy, że druga możliwość zakłada domyślny zaimek $\alpha$ U઼ do Chrystusa - por. w. 4) zgodny z logiką złożenia oúv (,z”). Wówczas

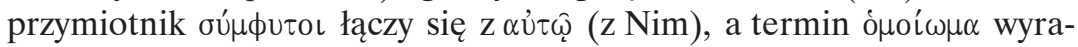
ża naszą relację do śmierci Chrystusa. Paweł podkreślałby, że wszyscy, którzy zostali zjednoczeni z Chrystusem, dostąpili tej łaski przez współudział w Jego śmierci ${ }^{43}$. Wydaje się, że ta druga interpretacja jest bardziej przekonywująca. Potwierdza ją chrystologiczny kontekst ${ }^{44}$ oraz tematyka zjednoczenia chrześcijanina ze śmiercią Jezusa, która w Rz 6, 4-8 pojawia się aż pięciokrotnie (por. ww. 4. 5. 6. 8bis) ${ }^{45}$.

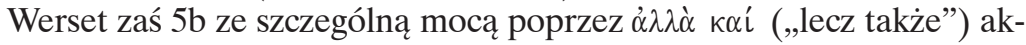
centuje nasze przyszłe zmartwychwstanie. Czasownik '́øó $\mu \in \theta \alpha$ („,będziemy”) stanowi eschatologiczne futurum, jak na to wskazuje paralelna wypowiedź

${ }^{38}$ Por. J. E. Toews, Romans, dz. cyt., s. 313.

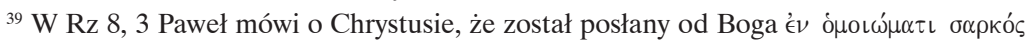
$\dot{\alpha} \mu \alpha \rho \tau$ ז́ $\alpha$. Oznacza to jednocześnie więź - Chrystus stał się człowiekiem, jak również różnicę - nie był On poddany grzechowi $(\dot{\alpha} \mu \alpha \rho \tau i \alpha)$. Podobnie w Flp 2, 7 wyrażenie: $\epsilon \nu$ ó $\mu$ oเ $\omega \mu \alpha \tau \iota \dot{\alpha} \nu \theta \hat{\rho}$

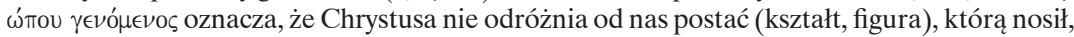
lecz noszący tę samą postać odróżniają się od Niego - por. E. Lohse, Der Brief an die Römer, Göttingen $2003^{15}$, s. 190-191 (Kritisch-exegetischer Kommentar über das Neue Testament, 4).

${ }^{40}$ Por. J. E. Toews, Romans, dz. cyt., s. 315.

${ }^{41}$ Por. S. Légasse, L'épître..., dz. cyt., s. 396.

${ }^{42}$ Por. R. Penna, Lettera ai Romani, dz. cyt., t. 2, s. 30.

${ }^{43}$ Por. tamże, s. 32.

${ }^{44}$ Paweł już wcześniej zaznaczył, że zostaliśmy ochrzczeni w Chrystusie (w. 3), pogrzebani z Nim (w. 4), a wreszcie doda, że nasz stary człowiek został współukrzyżowany, domyślnie z Nim, oraz że umarliśmy z Chrystusem i będziemy żyli z Nim (w. 8).

${ }^{45}$ Por. R. Penna, Battesimo..., dz. cyt., 166. 


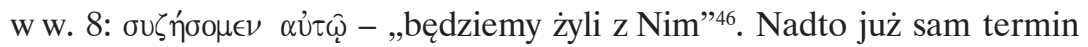
$\dot{\nu \alpha \alpha} \sigma \tau \alpha \sigma \iota \varsigma$ („,zmartwychwstanie”) wskazuje na przyszłość, ponieważ nigdy nie ma on u Pawła wartości teraźniejszej (por. Rz 1, 4; 1 Kor 15, 12-13. 21. 42; Flp 3, 10; $1 \mathrm{Tm} 2,18)^{47}$. Chrześcijanin już uczestniczy w śmierci Chrystusa, jest bowiem wyrwany z mocy grzechu. Pozostaje mu jeszcze współudział w Jego chwalebnym zmartwychwstaniu (por. Flp 3, 10). Na ten aspekt Paweł jednak nie zwraca większej uwagi. W następnym wersecie powraca do tematu śmierci względem grzechu i konieczności, by do niego więcej nie należeć.

Werset 6 pogłębia sens uczestnictwa w ukrzyżowaniu Chrystusa. Jest

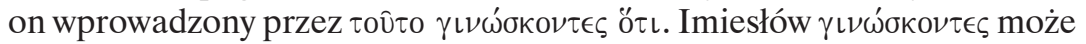
w tym przypadku zastępować formę osobową czasownika i mieć wartość nie tyle oznajmująca, co imperatywną ${ }^{48}$. Przytoczone wyrażenie można zatem przetłumaczyć: „to wiedzcie, że”.

Paweł pragnie skupić uwagę lektorów na treści, którą już podjął w poprzednich wersetach, teraz zaś ujmuje ją syntetycznie w formie niemalże

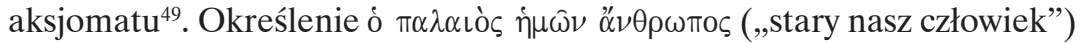
jest poprzedzone - jak widzimy - rodzajnikiem określonym. Wskazuje więc na kogoś konkretnego. Przymiotnik $\pi \alpha \lambda \alpha$ ıó życia ludzkiego przed chrztem i nawróceniem, akcentuje nasze Adamowe pochodzenie i przeszłość (por. 1 Kor 5, 7-8; Kol 3, 9; Ef 4, 22) ${ }^{50}$.

Stary człowiek utożsamia się więc z kimś, kto znajdował się lub znajduje poza Chrystusem. Był lub jest on zdominowany przez moc grzechu ${ }^{51}$. Tego

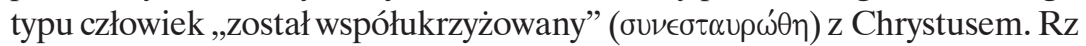
6, 6 stanowi jedyne miejsce w całym liście, w którym Paweł przywołuje krzyż Jezusa. Nie czyni jednak odniesienia do historycznej śmierci Chrystusa.

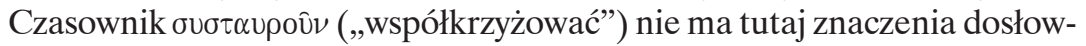
nego. Literalnie można go odnieść do dwóch łotrów ukrzyżowanych razem

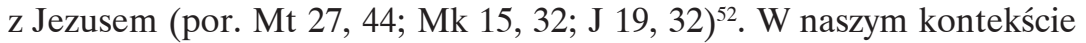
współukrzyżowanie chrześcijanina polega na współudziale w zbawczych owocach wypływających z ukrzyżowania Chrystusa ${ }^{53}$.

${ }^{46}$ Por. U. Wilckens, Der Brief an die Römer (Röm 6-11), Zürich 1993³3 s. 15 (Evangelischkatholischer Kommentar zum Neuen Testament, 6.2). Eschatologiczne futurum w w. 5 b tworzy fundament dla obecnego kroczenia w nowości życia - por. tamże, s. 16.

${ }^{47}$ Por. R. Penna, Lettera ai Romani, dz. cyt., t. 2, s. 33.

${ }^{48}$ Por. F. Blass, A. Debrunner, F. Rehkopf, Grammatik des neutestamentlichen Griechisch, dz. cyt., par. 468, 2b; H. Schlier, Der Römerbrief, dz. cyt., s. 195.

${ }^{49}$ Por. R. Penna, Lettera ai Romani, dz. cyt., t. 2, s. 34.

${ }^{50}$ Por. J. A. Fitzmyer, Lettera ai Romani, dz. cyt., s. 519.

${ }^{51}$ Por. A. Pitta, Lettera ai Romani, dz. cyt., s. 249.

${ }^{52}$ Por. S. Agersnap, Baptism and the New Life..., dz. cyt., s. 322.

${ }^{53}$ Por. R. Penna, Lettera ai Romani, dz. cyt., t. 2, s. 35. 
„Ciało grzechu” ( potęgę grzechu ${ }^{54}$ zostało uczynione dosłownie impotentem $^{55}$. To zaś oznacza, iż stary człowiek ${ }^{56}$ - niewolnik grzechu nie ma już żadnej siły działania. Został bowiem zastąpiony przez człowieka nowego (por. 2 Kor 5, 17), wyzwolonego z tyranii grzechu ${ }^{57}$. Człowiek nowy już nie jest na służbie grzechu, cieszy się wolnością, ponieważ przeszedł pod innego pana (por. Rz 6, 15-23).

Prawdę tę podkreśla także werset 7 , który brzmi jak ogólna sentencja ${ }^{58}$ : „Kto bowiem umarł, stał się wolnym od grzechu”. Być może Paweł nawiązał w niej do wypowiedzi rabinów: „Jeśli człowiek umarł, to jest wolny od wypełniania przykazań" ${ }^{9}$. Tekst rabiniczny mówi o śmierci fizycznej. Natomiast wydaje się, że Paweł, stosując tę sentencję, myśli o śmierci jako metaforze radykalnej odnowy człowieka ${ }^{60} \mathrm{i}$ rozumie ją duchowo jako śmierć dla grzechu ${ }^{61}$. Skutkiem współukrzyżowania z Chrystusem jest bowiem uwolnienie od mocy grzechu. Czasownik $\delta \iota \kappa \alpha\llcorner o v ̂ \theta \alpha \iota$ zachowuje więc tutaj inny sens niż zazwyczaj u Pawła („być usprawiedliwionym”) i oznacza „być wyzwolonym” (por. Syr 26, 29; Dz 13, 38n).

${ }^{54}$ Ciało grzechu nie wyraża opozycji do duszy, lecz określa całą osobę ukierunkowaną jedynie ku ziemi, zamkniętą na Boga i Jego Ducha - por. J. A. Fitzmyer, Lettera ai Romani, dz. cyt., s. 520.

${ }^{55}$ Por. A. Pitta, Lettera ai Romani, dz. cyt., s. 250, przyp. 165. Autor zaznacza, że czasownik $\kappa \alpha \tau \alpha \rho \gamma \epsilon \hat{\imath} \nu$ nie ma tutaj znaczenia mocnego („zniszczyć”), lecz słabe („czynić impotentem, nieskutecznym”).

${ }^{56}$ Ciało grzechu utożsamia się ze starym człowiekiem - por. R. Penna, Lettera ai Romani, dz. cyt., t. 2, s. 36 .

${ }^{57}$ Por. A. Pitta, Lettera ai Romani, dz. cyt., s. 251. Rodzi się pytanie, czy pozbawienie mocy ciała grzechu i wcześniejsze współukrzyżowanie dokonały się w akcie chrzcielnym, czy też należą do wydarzenia śmierci Chrystusa? Ściśle mówiąc o chrzcie jest mowa tylko w wersetach 3-4, natomiast werset 5 już od niego odbiega. Pierwszorzędne zainteresowanie Pawła dotyczy nie sakramentu, lecz śmierci Chrystusa. Egzegeza wersetu 6 potwierdza tę opcję hermeneutyczną.

${ }^{58}$ Por. H. Schlier, Der Römerbrief, dz. cyt., s. 198.

${ }^{59}$ Por. H. L. Strack, P. Billerbeck, Kommentar zum Neuen Testament aus Talmud und Midrasch, t. 3, München 1954, s. 232.

${ }^{60}$ Por. S. Agersnap, Baptism and the New Life..., dz. cyt., s. 322.

${ }^{61}$ Opinie wśród egzegetów są tutaj podzielone. Np. Pitta uważa, że Paweł myśli tutaj o śmierci fizycznej, która dotyczy każdego - por. A. Pitta, Lettera ai Romani, dz. cyt., s. 251. Natomiast Penna słusznie zauważa, iż kontekst jest rozstrzygający. Skoro śmierć fizyczna reprezentuje wyzwolenie z Prawa, to również ten, kto umiera z Chrystusem, jest wyzwolony z grzechu, ponieważ jest wolny od jego tyranii - por. R. Penna, Lettera ai Romani, dz. cyt., t. 2, s. 37. 


\section{Nasze przyszłe życie z Chrystusem}

oraz nowa wizja teraźniejszości (ww. 8-11)

Dotychczas Paweł zatrzymywał się przede wszystkim na uczestnictwie w śmierci Chrystusa, teraz zaś w w. 8 uwypukla współudział wierzących w życiu Jezusa w eschatologicznej przyszłości. W słowach Pawła rozbrzmiewa centralna treść chrześcijańskiej wiary ${ }^{62}$, kerygmat paschalny pierwotnego chrześcijaństwa (por. 1 Kor 15, 3-5). Jest on odczytany w świetle uczestnictwa chrześcijanina w losie Chrystusa. To, co odnosi się do Jezusa, dotyczy także na zasadzie analogii także tych, którzy do Niego należą ${ }^{63}$ (por. 1 Tes 4,14). Tekst zakłada śmierć Chrystusa i współudział w niej jako realnie zaistniałe (aoryst $\alpha \pi \epsilon \theta \dot{\alpha} \nu 0 \mu \epsilon \nu$ - „umarliśmy”), natomiast naszą pełną przynależność do Niego wyraża w eschatologicznym futurum

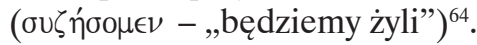

Apostoł podkreśla triumf Chrystusa nad śmiercią (w. 9). Zmartwychwstanie ma dla Niego charakter fizyczny, natomiast dla chrześcijanina moralny i fizyczny ${ }^{65}$.

Zmartwychwstały Jezus nie podlega już imperium śmierci ${ }^{66}$. Jego powstanie z martwych nie jest powrotem do życia naturalnego, jak to było

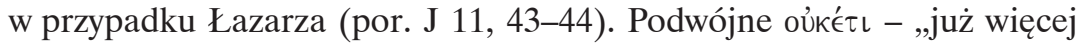
nie" (w. 9) kładzie nacisk na to, że pokonał On śmierć w sposób definitywny. Przysłówek '́фф́ं $\alpha \xi$ - „raz na zawsze” (w. 10) ma sens soteriologiczny i zaznacza niepowtarzalność, czyli wystarczalność śmierci Chrystusa, aby przynieść nam radykalne wyzwolenie ${ }^{67}$. Tekst wyraża je celownikiem $\tau \hat{n}$ $\dot{\alpha} \mu \alpha \rho \tau i \alpha$, który funkcjonuje jako dativus incommodi ${ }^{68}$. Podkreśla on, że Chrystus umarł dla grzechu, to znaczy przyniósł mu ujmę, szkodę, zadał mu cios. W ten sposób radykalnie wyzwolił człowieka spod jego wpływu. Konstrukcja $\tau \hat{n} \hat{\alpha} \mu \alpha \rho \tau \dot{\imath} \alpha \alpha^{\prime} \pi^{\prime} \theta \alpha \nu \in \nu$ (,umarł dla grzechu”) stanowi także fundament wobec tego, co Paweł wyraził w 6, 2 w odniesieniu do chrześcijan: „umarliśmy dla grzechu”69. Nowe życie Chrystusa jest teocentryczne.

${ }^{62}$ Por. U. Wilckens, Der Brief an die Römer (Röm 6-11), dz. cyt., s. 18.

${ }^{63}$ Por. R. Penna, Leterra..., dz. cyt., t. 2, s. 37. Autor zwraca uwage, iż podmiot w wersecie 8 nie jest w 3 os. 1. poj., lecz w 1 os. l. mn.

${ }^{64}$ Por. E. Lohse, Der Brief an die Römer, dz. cyt., s. 192.

${ }^{65}$ Por. R. Penna, Leterra..., dz. cyt., t. 2, s. 39.

${ }^{66}$ S. Légasse, L'épître..., dz. cyt., s. 402.

${ }^{67}$ Por. R. Penna, Leterra..., dz. cyt., t. 2, s. 39.

${ }^{68}$ Por. F. Blass, A. Debrunner, F. Rehkopf, Grammatik des neutestamentlichen Griechisch, dz. cyt., par. 188, 3 .

${ }^{69}$ Por. R. Penna, Lettera ai Romani, dz. cyt., t. 2, s. 39. 
Celownik $\tau \hat{̣}$ $\theta \in \hat{\omega}$ stanowi z kolei dativus commodi i wyraża cel osiągnięty przez Chrystusa: życie dla Boga ${ }^{70}$.

W ten nowy sposób istnienia Chrystus pragnie wprowadzić także swych wiernych. Dlatego też Paweł zwraca się do nich bezpośrednio w drugiej

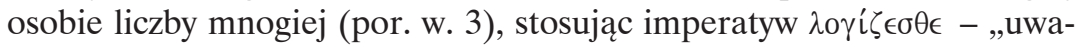
żajcie, bądźcie przekonani, liczcie się z faktem, że...” (w. 11). Czasownik $\lambda o \gamma i \zeta \in \sigma \theta \alpha \iota \mathrm{w}$ Liście do Rzymian nie przekazuje jakiejśs subiektywnej opinii, lecz wyraża mocne przekonanie, pewność wynikającą z wiary (por. Dz 3, $28)^{71}$. Pawłowe stwierdzenie brzmi jako zasada, fundament. Dotyczy bycia, a nie działania ${ }^{72}$. Ponieważ Chrystus umarł dla grzechu (por. w. 10), chrze-

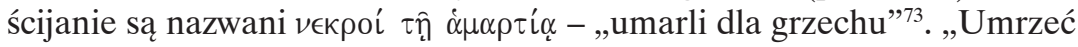
dla grzechu" ma jednak w odniesieniu do Chrystusa inny sens niż w relacji do chrześcijan. Chrystus zdetronizował grzech, chrześcijanie zaś czerpią owoce z tej detronizacji, bo nie są już mu poddani ${ }^{74}$.

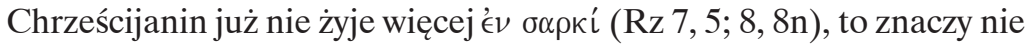

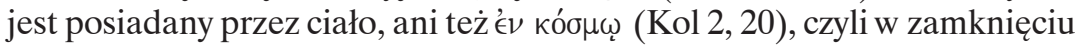

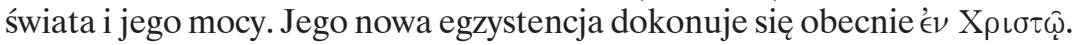
W Rz 6, 11 Paweł po raz pierwszy stosuje $€ \mathcal{\epsilon} \nu-$ w połączeniu z Chrystusem. Przyimek '́v (,w”) wyraża intymną i witalną więź z Nim. Dla Pawła „żyć dla

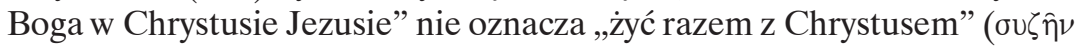
$\mathrm{X}\left\llcorner\sigma \tau(\hat{)})\right.$, ale odpowiada obecnie tej przyszłej perspektywie ${ }^{75}$.

\section{Końcowe zachęty (ww. 12-14)}

Wersety 12-14 mają charakter parenezy, zawierają wnioski etyczne i zachęty wypływające z uczestnictwa w śmierci Chrystusa. Chociaż miejsce

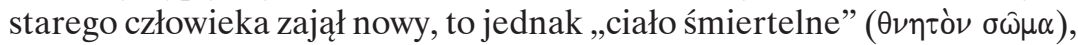
w którym zrealizowała się ta głęboka przemiana, pozostaje to samo $^{76}$.

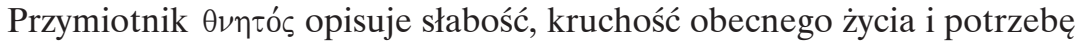
przyszłego zmartwychwstania (por. Rz 8, 11; 1 Kor 15, 53. 54; 2 Kor 4, 11; $5,4)$. Natomiast rzeczownik $\sigma \hat{\omega} \mu \alpha$ nie określa jedynie wymiaru fizycznego

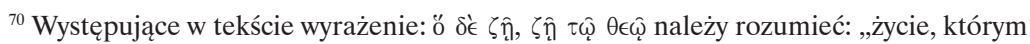
żyje, żyje dla Boga". Podobnie tłumaczy się wcześniejsze ő $\gamma \grave{\alpha} \rho$. Wskazuje ono na śmierć Chrystusa - por. F. Blass, A. Debrunner, F. Rehkopf, Grammatik des neutestamentlichen Griechisch, dz. cyt., par. 154, 3.

${ }^{71}$ Por. E. Lohse, Der Brief an die Römer, dz. cyt., s. 193.

${ }^{72}$ Por. R. Penna, Lettera ai Romani, dz. cyt., t. 2, s. 41.

${ }^{73}$ Por. H. Schlier, Der Römerbrief, dz. cyt., s. 200.

${ }^{74}$ Por. R. Penna, Lettera ai Romani, dz. cyt., t. 2, s. 41.

${ }^{75}$ Por. H. Schlier, Der Römerbrief, dz. cyt., s. 201.

${ }^{76}$ Por. A. Pitta, Lettera ai Romani, dz. cyt., s. 253. 
człowieka, lecz całą osobę ludzką ${ }^{77}$. W śmiertelnym ciele budzą się pożądania, które są pozostałymi agentami grzechu (por. Rz 7, 7n) i usiłują zdominować wierzących ${ }^{78}$.

Należą one do starego człowieka. Moc grzechu może się znów odezwać w kimś, kto porzuca relację uczestnictwa w śmierci Chrystusa ${ }^{79}$. Stąd rodzi się Pawłowy apel, by nie dać się ponownie zwyciężyć przez grzech. Jego niewolniczy wpływ objawia się we wspomnianych już pożądliwościach. Dla-

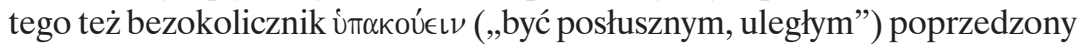

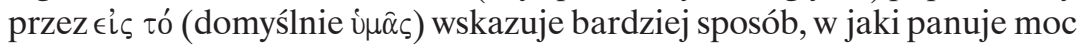
grzechu, aniżeli jego skutek ${ }^{80}$.

W dalszym ciągu parenezy Paweł stosuje drugą osobę liczby mnogiej, nawiązuje więc bezpośredni kontakt z wierzącymi. Nadto posługuje się językiem obrazowym, mającym wydźwięk militarny. Apostoł widzi obecne życie jako walkę między bronią niesprawiedliwości i bronią sprawiedliwości (ö $\pi \alpha \alpha \dot{\alpha} \delta\left\llcorner\kappa i \alpha \varsigma, ~ o ̋ \pi \lambda \alpha \delta\left\llcorner\kappa \alpha\llcorner o \sigma u ́ \nu \eta \varsigma)^{81}\right.\right.$. Chrześcijanin umarł dla grzechu, ale grzech nie przestaje istnieć, dlatego też Apostoł apeluje do chrześcijan, by oddali swe członki, czyli samych siebie ${ }^{82}$, na służbę Bogu, a nie grzechowi. Powtórzenie zaś tego samego czasownika $\pi \alpha \rho \iota \sigma \tau \alpha \dot{\nu} \in \iota \nu$ („oddać, ofiarować, przedstawić”) zwraca uwagę na ważność i właściwy wymiar życia chrześcijańskiego, który się odmierza i żywi relacją z Bogiem ${ }^{83}$.

$\mathrm{W}$ ostatnim wersecie parenezy Paweł podejmuje tezę wyrażoną w w. 1b, iż nie ma zgodności między łaską a grzechem, ponieważ nie można być jednocześnie pod panowaniem łaski i grzechu. Łaska zapoczątkowała nową ontologię chrześcijanina (umarły dla grzechu) i jednocześnie towarzyszy mu w jego nieustannej walce moralnej ${ }^{84}$. Dała początek nowemu porządkowi

${ }^{77}$ Por. R. Penna, Lettera ai Romani, dz. cyt., t. 2, s. 43.

${ }^{78}$ Por. U. Wilckens, Der Brief an die Römer (Röm 6-11), dz. cyt., s. 20.

${ }^{79}$ Por. A. Pitta, Lettera ai Romani, dz. cyt., s. 253.

${ }^{80}$ Por. H. Schlier, Der Römerbrief, dz. cyt., s. 202.

${ }^{81}$ Zaskakuje przeciwstawna relacja między niesprawiedliwością a sprawiedliwością ze względu na całkowity brak słownictwa dotyczącego sprawiedliwości w Rz 6, 1-14 (jedynie

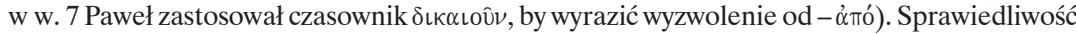
w 6,13 jest rozumiana w sensie postawy wobec Boga wynikającej z usprawiedliwienia - por. A. Pitta, Lettera ai Romani, dz. cyt., s. 253. Ma wydźwięk nowego życia w Chrystusie. Natomiast niesprawiedliwość zgodnie z Rz 6, 19 wiąże się z nieczystością, nieprawością - por. J. A. Fitzmyer, Lettera ai Romani, dz. cyt., s. 532.

${ }^{82}$ Zwrot „nasze członki” jest paralelny do zwrotu „my sami” - por. G. Rafiński, Grzech ludzkości i dar usprawiedliwienia (List św. Pawła do Rzymian), [w:] Wprowadzenie w myśl

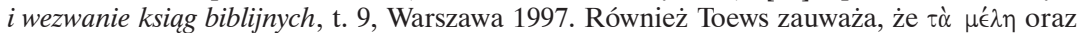
Ł̇avtoúc są synonimami - por. J. E. Toews, Romans, dz. cyt., s. 323.

${ }^{83}$ Por. R. Penna, Lettera ai Romani, dz. cyt., t. 2, s. 47.

${ }^{84}$ Por. tamże, s. 146. 
zbawienia, dzięki śmierci i zmartwychwstaniu Chrystusa. Grzech natomiast jest związany z Prawem Mojżeszowym ${ }^{85} \mathrm{w}$ tym sensie, że nie daje ono możliwości wyzwolenia spod mocy grzechu ${ }^{86}$. Cały akcent jednak pada na łaskę (oủ... $\dot{\alpha} \lambda \lambda \dot{\alpha} \ldots$ - „nie... lecz...”), która ma przypominać, że grzech nie może być naszym panem, lecz Jezus Chrystus.

\section{Wnioski}

Perykopa Rz 6, 1-14 daje wyraźną odpowiedź na tezę wyrażoną w formie zarzutu: „Czy mamy trwać w grzechu, aby wzmogła się łaska?”. W przeprowadzonej argumentacji Paweł w sposób jasny ukazuje bezsensowność takiego pytania. Jak mogą chrześcijanie trwać w grzechu, skoro dla niego umarli, zostali współpogrzebani, współukrzyżowani z Chrystusem? Nadto otworzył się przed nimi nieznany dotąd sposób życia. Otrzymali nowy początek, nową przyszłość. Grzech stracił nad nimi swą zniewalającą moc. Eschatologiczne życie zobowiązuje ich, aby trwali w zażyłości z Chrystusem, byli stale ukierunkowani ku Bogu i zdeterminowani w walce, by nie dać się opanować przez grzech.

Kraków

STANISEAW WITKOWSKI MS

\section{Słowa kluczowe}

Paweł Apostoł, List do Rzymian, grzech, łaska, moc, pogrzebani z Chrystusem, ukrzyżowani z Chrystusem, nowe życie

\section{Summary}

\section{Crucified with Christ and free from the power of $\sin (\operatorname{Rom} 6,1-14)$}

Pericope Rom 6, 1-14 gives a clear answer to a thesis expressed in the form of accusation: should we remain in sin so that grace may be given the more fully? In his argumentation Paul clearly illustrates the absurdity of this question. How can we remain in sin if we have died for it, were buried and crucified with Christ? Furthermore, a new, until now unknown, way of life opened before us. We received a new beginning and new future. Sin lost its enslaving power over us. The reality of eschatological life obliges us to remain in intimacy with Christ, to be steered towards God and determined in the fight not to be overcome by $\sin$.

${ }^{85}$ Rzeczownik vó vó $\mu$ o w żadnym wypadku nie jest argumentem przeciwko odniesieniu do Prawa Mojżeszowego - por. J. E. Toews, Romans, dz. cyt., s. 326.

${ }^{86}$ Por. A. Pitta, Lettera ai Romani, dz. cyt., s. 254. Być pod Prawem nie jest tym samym, co być pod grzechem, choćby ze względu na Boże pochodzenie Prawa. Jednak z punktu widzenia antropologicznego, sytuacja człowieka nie zmienia się. 


\section{Keywords}

Paul the Apostle, Letter to the Romans, sin, grace, power, buried with Christ, crucified with Christ, new life 